\title{
Prevalence of Vibrio spp. with special reference to Vibrio parahaemolyticus in farmed penaeid shrimp Penaeus vannamei (Boone, 1931) from selected districts of Tamil Nadu, India
}

\author{
R. ANANDA RAJA ${ }^{1,3}$, R. SRIDHAR ${ }^{1}$, C. BALACHANDRAN ${ }^{1}$, A. PALANISAMMI $^{1}$, \\ S. RAMESH ${ }^{2}$ AND K. NAGARAJAN ${ }^{1}$ \\ ${ }^{1}$ Madras Veterinary College, Chennai - 600 007, Tamil Nadu, India \\ ${ }^{2}$ Laboratory Animal Medicine, Centre for Animal Health Studies, Tamil Nadu Veterinary and Animal Sciences \\ University, Chennai - 600 051, Tamil Nadu, India \\ ${ }^{3}$ Aquatic Animal Health and Environment Division, ICAR-Central Institute of Brackishwater Aquaculture \\ Chennai - 600 028, Tamil Nadu, India \\ e-mail:anandarajars@gmail.com
}

\begin{abstract}
Prevalence of Vibrio spp. with special reference to Vibrio parahaemolyticus ( Vp) infection was assessed in Penaeus vannamei farms in Kancheepuram and Thiruvallur districts of Tamil Nadu during the period August 2014 to February 2015. Isolation and identification of bacteria from haemolymph, stomach and hepatopancreas of $P$. vannamei was done from all the farms for the prevalence of $V p$ infection. Based on the morphological, physiological and biochemical characterisation, 74 isolates were identified as $V p(35.14 \%)$, V. harveyi $(21.62 \%)$, V. anguillarum (16.22\%), V. campbellii (10.81\%), V. mimicus $(8.11 \%)$, V. alginolyticus $(5.41 \%)$ and Pseudomonas aeruginosa $(2.7 \%)$. The PCR results showed that there were $26(35.14 \%)$ isolates positive for $V p$ specific toxR and $t h$ genes and negative for human pathogenic $t d h$ and $t r h$ genes. All isolates were also negative for acute hepatopancreatic necrosis disease (AHPND) specific AP1, AP2, AP3 (pir $A^{v p}$ ) and AP4 $\left(\operatorname{pir}^{v p}\right.$ and $\operatorname{pir}^{v p}$ ) genes. The study revealed that there was no AHPND causing $V p$ strain in farmed $P$. vannamei from two important coastal districts of Tamil Nadu, India.
\end{abstract}

Keywords: Acute hepatopancreatic necrosis disease (AHPND), Early mortality syndrome (EMS), Penaeus vannamei, Vibriosis, Vibrio parahaemolyticus

Over the last couple of decades, several diseases such as luminous vibriosis, white spot disease (WSD), yellow head disease (YHD) and taura syndrome (TS) caused catastrophic devastation in the shrimp aquaculture, causing the collapse of Penaeus monodon culture. As an alternate species, Penaeus. vannamei (Boone, 1931) was introduced in India during 2009. The growth in production of this exotic species in India has been stupendous. Any disease outbreak in this sector is considered to be important nationally and globally. Recently, a newly emerging disease known as early mortality syndrome (EMS) in shrimp (P. vannamei, P. monodon and $P$. chinensis), renamed as acute hepatopancreatic necrosis disease [AHPND] (NACA, 2012; FAO, 2013) caused by a strain of Vibrio parahaemolyticus $\left(V_{P}\right)$ has been reported to cause unusually high mortality and morbidity within the first 30 days of culture (DOC) and led to a significant loss of one billion USD in Asia-Pacific region (FAO, 2013; Tran et al., 2013). In terms of impacts on trade, several countries have suspended or banned the import of live shrimp and/ or all forms of shrimp products from countries affected by AHPND (FAO, 2013). Keeping all these factors in view, the present study was carried out on prevalence of AHPND causing $V_{P}$ isolates and natural occurrence of $V_{P}$ infection in $P$. vannamei farms of Tamil Nadu, India.

A total of 37 shrimp farms were screened during August 2014 to February 2015. Initial bacterial isolations were made from haemolymph of infected moribund animals using thiosulphate citrate bile salts sucrose (TCBS) agar plates (Zhou et al., 2012; Ananda Raja et al., 2017b). The stomach and hepatopancreas from representative shrimp were enriched in tryptone soya broth (TSB) for $12 \mathrm{~h}$ and spread plated on TCBS plates for further isolation and identification (Antonio et al., 2015; Ananda Raja et al., 2017b). Thus, 74 well-separated colonies two from each pond were selected, further purified, screened and identified based on the morphological, physiological, biochemical (Baumann and Schubert, 1984; Alsina and Blanch, 1994) and molecular characterisation. For long term preservation, these isolates were stored at $-20^{\circ} \mathrm{C}$ in TSB with $25 \%(\mathrm{v} / \mathrm{v})$ glycerol. 
The isolates were cultured overnight in TSB and genomic DNA of all Vibrio isolates were extracted by standard phenol-chloroform method. DNA was also extracted from all Vibrio isolates by boiling for $10 \mathrm{~min}$ and used as templates for PCR assays (Hossain et al., 2013; Han et al., 2015). The isolated DNA was quantified by spectrophotometric method and checked in $1 \%$ agarose gel electrophoresis and stored at $-80^{\circ} \mathrm{C}$ for further use. Polymerase chain reaction (PCR) was carried out in a gradient thermal cycler (Eppendorf) for toxR (Kim et al., 1999), th (Nordstrom et al., 2007), tdh, trh (Bej et al., 1999), AP1, AP2 (Flegel and Lo, 2014), AP3 (pirA ${ }^{v p}$ ) and AP4 (pirA ${ }^{v p}$ and pirB ${ }^{v p}$ ) (Dangtip et al., 2015) genes. The amplified PCR products were analysed by agarose gel electrophoresis and visualised under UV transilluminator. PCR products were eluted using GenElute ${ }^{\mathrm{TM}}$ Gel Extraction Kit (Sigma) as per the manufacturer's instructions and used for sequencing by di-deoxy chain termination method. The nucleotide sequence obtained was assembled using Auto assembler (ABI Prism, USA) software. The isolates were identified by BLAST (Basic local alignment search tool) search in the, NCBI (National Center for Biotechnology Information) database based on the maximum percentage of homology (Ananda Raja et al., 2017b) and the identified sequences were submitted to the NCBI GenBank database.

Based on the morphological, physiological and biochemical parameters, 74 isolates collected were characterised (Table 1). The isolates were identified as $V$. parahaemolyticus $\left(V_{P}\right)(35.14 \%)$, V. harveyi $(21.62 \%)$, V. anguillarum (16.22\%), V. campbellii (10.81\%), $V$. mimicus (8.11\%), V. alginolyticus (5.41\%) and Pseudomonas aeruginosa (2.7\%) (Ananda Raja et al., 2017b). $V_{P}$ was morphologically identified based on curved, rod-shaped and Gram negative characteristics (Baumann and Schubert, 1984; Johnson et al., 2012; Janakiram et al., 2013). $V_{P}$ isolate was found to be sensitive to heat and reduction in cells to non-detectable levels at $55^{\circ} \mathrm{C}$ for $5 \mathrm{~min}$ (Lightner et al., 2013) as observed in the present study. The present study also revealed that the $V_{p}$ did not grow in peptone water at $4^{\circ} \mathrm{C}$ after $18 \mathrm{~h}$ incubation and did not survive at $-18^{\circ} \mathrm{C}$ to $-20^{\circ} \mathrm{C}$ after 30 days of incubation. Similarly, Zorriehzahra and Banaederakhshan (2015) reported that the refrigeration at $4{ }^{\circ} \mathrm{C}$ for 38 days and freezing for 27 days caused considerable reductions in cells at non-detectable levels. Furthermore, morphological, physiological and biochemical identification concurred with the results of Alsina and Blanch (1994), Jayasree et al. (2000) and Janakiram et al. (2013). The present study showed that $V_{P}$ isolates were predominant $(35.14 \%)$ among $P$. vannamei samples as observed by Sudha et al. (2014) in shellfish samples but Rosalind George (2002) identified
$V$. alginolyticus $(41.73 \%)$ as the most abundant species found in $P$. monodon culture pond water followed by $V$. harveyi $(18.7 \%), V$. marinus $(6.78 \%), V_{P}(5.15 \%)$, $V$. vulnificus $(5.15 \%), \quad V$. logei $(4.61 \%), \quad V$. mimicus $(3.52 \%), V$. cholera $(3.25 \%), V$. orientalis $(2.71 \%)$, V. splendidus II (2.44\%), V. fluvialis (1.24\%), V. fischeri (1.08\%), V. metschnikovii (1.08\%), V. anguillarumlike $(0.54 \%), V$. campbellii $(0.54 \%), V$. splendidus I $(0.54 \%), \quad V$. damsela $(0.27 \%)$ and $V$. cincinnatiensis $(0.27 \%)$. Vibriosis in shrimp was usually associated with major Vibrio spp. such as Vibrio harveyi, $V$. splendidus, $V$. cholerae, $V$. penaeicida, V. alginolyticus, $V$. anguillarum, $V_{P}, V$. vulnificus, $V$. campbelli, $V$. mimicus and $V$. nigripulchritudo. Many researchers reported that the opportunistically pathogenic Vibrio species were the major cause of disease problems in shrimp aquaculture in several parts of the world (Lavilla-Pitogo et al., 1990; Ishimaru et al., 1995; Jayasree et al., 2000; Alday-Sanz et al., 2002; Ananda Raja et al., 2012; Zhang et al., 2012; Tran et al., 2013; De Schryver et al., 2014; Ananda Raja et al., 2017a).

Twenty six (35.14\%) isolates were positive for $V_{P}$ specific toxR and th genes (Fig. 1,2) as observed in morphological, physiological and biochemical characterisation (Ananda Raja et al., 2017b). Similarly, Silvester et al. (2015) confirmed 75 isolates as $V_{P}$ using a PCR assay targeting the species-specific $t$ th gene and found that the prevalence of $V_{P}$ was $71.6 \%$ in the Cochin Estuary and $53.3 \%$ in the shrimp farms. Letchumanan et al. $(2015 \mathrm{a}, \mathrm{b})$ indicated that a total of 57.8 and $44.4 \%$ isolates were positive for $V_{P}$ with toxR-based PCR assay. The present study revealed that the prevalence of $V_{P}$ in shrimp farms were lower $(35.14 \%)$ than the previous results. All the 74 isolates were found to be negative for human pathogenic $t d h$ and trh genes (Ananda Raja et al., 2017b). Those isolates were also found to be non AHPND causing $V_{P}$ strains using standard protocols (Kumar et al., 2014; Ananda Raja et al., 2017b). The PCR products of toxR forward and reverse showed that they had 99 and 98\% homology with $V_{P}$ RIMD 2210633 chromosome 1 while the PCR products of th forward and reverse confirmed that they had 96 and 99\% homology with $V_{P}$ RIMD 2210633 chromosome 2. Respective NCBI accession numbers obtained were KT360934 and KT360935 for ToxR gene and KT360936 and KT360937 for $t$ lh gene (Ananda Raja et al., 2017b). The PCR products of tox $R$ forward and reverse showed that they had 99 and 98\% homology with $V_{P}$ RIMD 2210633 chromosome 1. There was deletion of $\mathrm{T}$ at $29^{\text {th }}$, replacement of A with $\mathrm{T}$ at $85^{\text {th }}, \mathrm{G}$ with $\mathrm{A}$ at $232^{\text {nd }}$ and $\mathrm{A}$ with $\mathrm{G}$ at $265^{\text {th }}$ positions in forward sequence while it was deletion of $\mathrm{T}$ and $\mathrm{A}$ at $4^{\text {th }}$ and $30^{\text {th }}$ position and replacement of $\mathrm{C}$ with $\mathrm{T}$ at $67^{\text {th }}, \mathrm{T}$ with $\mathrm{A}$ at $190^{\text {th }}$, A with $\mathrm{T}$ at $259^{\text {th }}$ and $292^{\text {nd }}$ positions in 
Table 1. Morphological, physiological and biochemical characterisation of bacterial isolates collected from shrimp ponds

\begin{tabular}{|c|c|c|c|c|c|c|c|}
\hline Characteristics & $V_{P}(26)$ & $\begin{array}{l}\text { V. harveyi } \\
\text { (16) }\end{array}$ & $\begin{array}{l}\text { V. anguillarum } \\
\text { (12) }\end{array}$ & $\begin{array}{l}\text { V. campbellii } \\
\text { (8) }\end{array}$ & $\begin{array}{l}\text { V. mimicus } \\
\text { (6) }\end{array}$ & $\begin{array}{l}\text { V. alginolyticus } \\
\text { (4) }\end{array}$ & $\begin{array}{l}\text { P. aeruginosa } \\
\text { (2) }\end{array}$ \\
\hline Configuration & Round & Round & Round & Round & Round & Round & Round \\
\hline Margin & Entire & Entire & Serrated & Entire & Entire & Entire & Entire \\
\hline Elevation & Convex & Convex & Convex & Convex & Convex & Convex & Convex \\
\hline Surface & Smooth & Smooth & Smooth & Smooth & Smooth & Smooth & Smooth \\
\hline Density & Opaque & Opaque & Opaque & Opaque & Opaque & Opaque & Opaque \\
\hline Texture & Moist & Moist & Moist & Moist & Moist & Moist & Moist \\
\hline $\begin{array}{l}\text { Colour on: } \\
\text { Nutrient agar }\end{array}$ & Creamy & Creamy & Creamy & Creamy & Creamy & Creamy & Creamy \\
\hline TCBS agar & Blue-green & Yellow & Yellow & Green & Green & Yellow & Green \\
\hline Cell morphology & Rod often curved & Straight rod & Curved rod & Rod & Short rod & Straight rod & Rod often curved \\
\hline Size & Short & Short & Short & Short & Short & Short & Short \\
\hline Arrangements & Single & Single & Single & Single & Single & Single & Single \\
\hline Flagella & Single & $\begin{array}{l}\text { Polar and lateral } \\
\text { flagella }\end{array}$ & Single & Single & Single & Single & Single \\
\hline Swarming & - & $\mathrm{V}$ & - & - & - & $\mathrm{V}$ & - \\
\hline Motility & + & + & + & + & + & + & + \\
\hline Luminescence & - & - & - & - & - & - & + \\
\hline Gram staining & - & - & - & - & - & - & - \\
\hline Spore forming & - & - & - & - & - & - & - \\
\hline \multicolumn{8}{|l|}{$\begin{array}{l}\text { Growth in peptone } \\
\text { with } \mathrm{NaCl} \text { : }\end{array}$} \\
\hline $0 \%$ & + & - & - & - & + & - & - \\
\hline $2 \%$ & + & + & + & + & + & + & + \\
\hline $4 \%$ & + & + & + & + & + & + & + \\
\hline $6 \%$ & + & + & + & + & + & + & + \\
\hline $8 \%$ & + & + & + & + & - & + & + \\
\hline $10 \%$ & - & - & - & - & - & + & - \\
\hline $\begin{array}{l}\text { Survival } \\
\text { at }-18 \text { to }-20^{\circ} \mathrm{C}\end{array}$ & - & - & - & - & - & - & - \\
\hline \multicolumn{8}{|c|}{ Growth in peptone at: } \\
\hline $4^{\circ} \mathrm{C}$ & - & - & - & - & - & - & - \\
\hline $20^{\circ} \mathrm{C}$ & + & + & + & + & + & + & + \\
\hline $30^{\circ} \mathrm{C}$ & + & + & + & + & + & + & + \\
\hline $35^{\circ} \mathrm{C}$ & + & + & + & + & + & + & + \\
\hline $40^{\circ} \mathrm{C}$ & + & + & - & - & + & + & + \\
\hline $55^{\circ} \mathrm{C}$ & - & - & - & - & - & - & - \\
\hline Anaerobic growth & - & - & - & - & - & - & - \\
\hline \multicolumn{8}{|l|}{ Decarboxylation of } \\
\hline Arginine & - & - & + & - & - & - & + \\
\hline Lysine & + & + & - & + & + & + & - \\
\hline Ornithine & + & \pm & - & - & + & + & - \\
\hline \multicolumn{8}{|l|}{$\begin{array}{l}\text { Production of extra- } \\
\text { cellular enzymes }\end{array}$} \\
\hline Gelatinase & + & + & + & + & + & + & + \\
\hline Urease & \pm & - & \pm & - & - & - & \pm \\
\hline Gas production from & - & & & & & & \\
\hline Glucose & & - & - & - & - & - & - \\
\hline Oxidation/ & & & & & & & \\
\hline Fermentation & $-/+$ & $-/+$ & $-/+$ & $-/+$ & $+/-$ & $-/+$ & $+/-$ \\
\hline Methyl red test & + & + & + & + & - & + & + \\
\hline
\end{tabular}




\begin{tabular}{|c|c|c|c|c|c|c|c|}
\hline Characteristics & $V_{P}(26)$ & $\begin{array}{l}\text { V. harveyi } \\
\text { (16) }\end{array}$ & $\begin{array}{l}\text { V. anguillarum } \\
\text { (12) }\end{array}$ & $\begin{array}{l}\text { V. campbellii } \\
\text { (8) }\end{array}$ & $\begin{array}{l}\text { V. mimicus } \\
\text { (6) }\end{array}$ & $\begin{array}{l}\text { V. alginolyticus } \\
\text { (4) }\end{array}$ & $\begin{array}{l}\text { P. aeruginosa } \\
\text { (2) }\end{array}$ \\
\hline Voges-Proskauer & - & + & + & - & - & + & + \\
\hline Nitrate reduction & + & - & + & + & - & + & + \\
\hline Indole & + & \pm & + & + & - & - & + \\
\hline Catalase & + & + & + & + & + & + & + \\
\hline Oxidase & + & - & + & + & - & + & + \\
\hline Citrate utilisation & + & + & + & + & + & + & + \\
\hline $\begin{array}{l}\text { Ortho-Nitrophenyl- } \beta \text { - } \\
\text { Galactosidase (ONPG) }\end{array}$ & - & - & + & - & + & - & - \\
\hline \multicolumn{8}{|l|}{ Acid production } \\
\hline Positive & $\begin{array}{l}\mathrm{Ce}, \mathrm{Fc}, \mathrm{Gl}, \mathrm{Ma}, \\
\mathrm{Mb}, \mathrm{Mn}, \mathrm{Mo} \\
\mathrm{Sb} \text { and } \mathrm{Te}\end{array}$ & $\begin{array}{l}\mathrm{Fc}, \mathrm{Gl}, \mathrm{Ma}, \mathrm{Mn} \\
\mathrm{Mo}, \mathrm{Su} \text { and Te }\end{array}$ & $\begin{array}{l}\mathrm{Ar}, \mathrm{Ce}, \mathrm{Fc}, \mathrm{Ga} \text {, } \\
\mathrm{Gl}, \mathrm{Ma}, \mathrm{Mn}, \\
\mathrm{Mo}, \mathrm{Sb}, \mathrm{Su}, \mathrm{Te} \\
\text { and Xy }\end{array}$ & $\begin{array}{l}\mathrm{Ce}, \mathrm{Fc}, \mathrm{Ma} \\
\mathrm{Mn}, \mathrm{Mo} \\
\text { and Te }\end{array}$ & $\begin{array}{l}\text { Fc, Gl, Ma, } \\
\mathrm{Mb}, \mathrm{Mn}, \\
\mathrm{Mo}, \mathrm{Sb} \\
\text { and Te }\end{array}$ & $\begin{array}{l}\mathrm{Fc}, \mathrm{Ga}, \mathrm{Gl}, \\
\mathrm{Ma}, \mathrm{Mb}, \mathrm{Mn}, \\
\mathrm{Mo}, \mathrm{Su} \text { and } \mathrm{Te}\end{array}$ & $\begin{array}{l}\mathrm{Ad}, \mathrm{Ar}, \mathrm{Ce}, \mathrm{Fc} \text {, } \\
\mathrm{Ga}, \mathrm{Gl}, \mathrm{Ma}, \\
\mathrm{Mb}, \mathrm{Mn}, \mathrm{Mo}, \\
\mathrm{Sb}, \mathrm{Te} \text { and Xy }\end{array}$ \\
\hline Negative & $\begin{array}{l}\mathrm{Ad}, \mathrm{Ar}, \mathrm{Du}, \mathrm{Ga}, \mathrm{Is} \text {, } \\
\mathrm{La}, \mathrm{Rf}, \mathrm{Sa} \text {, } \\
\text { Su and Xy }\end{array}$ & $\begin{array}{l}\mathrm{Ad}, \mathrm{Ar}, \mathrm{Ce}, \mathrm{Du}, \\
\mathrm{Ga}, \mathrm{Is}, \mathrm{La}, \mathrm{Mb}, \\
\mathrm{Rf}, \mathrm{Sa}, \mathrm{Sb} \text { and } \mathrm{Xy}\end{array}$ & $\begin{array}{l}\text { Ad, } \mathrm{Du}, \mathrm{Is}, \mathrm{La}, \\
\mathrm{Mb}, \mathrm{Rf} \text { and } \mathrm{Sa}\end{array}$ & $\begin{array}{l}\mathrm{Ad}, \mathrm{Ar}, \mathrm{Du}, \\
\mathrm{Ga}, \mathrm{Gl}, \mathrm{Is}, \\
\mathrm{La}, \mathrm{Mb}, \mathrm{Rf}, \\
\mathrm{Sa}, \mathrm{Sb}, \mathrm{Su} \text { and } \\
\text { Xy }\end{array}$ & $\begin{array}{l}\text { Ad, Ar, Ce, } \\
\mathrm{Du}, \mathrm{Ga}, \mathrm{Is}, \\
\mathrm{La}, \mathrm{Rf}, \mathrm{Sa}, \\
\mathrm{Su} \text { and } \mathrm{Xy}\end{array}$ & $\begin{array}{l}\mathrm{Ad}, \mathrm{Ar}, \mathrm{Ce}, \mathrm{Du} \text {, } \\
\text { Is, La, Rf, Sa, } \\
\mathrm{Sb} \text { and Xy }\end{array}$ & $\begin{array}{l}\mathrm{Du}, \mathrm{Is}, \mathrm{La}, \mathrm{Rf} \\
\mathrm{Sa} \text { and } \mathrm{Su}\end{array}$ \\
\hline
\end{tabular}

Ad - Adonitol, Ar - Arabinose, Ce - Cellobiose, Du - Dulcitol, Fc - Fructose, Ga - Galactose, Gl - Glucose, Is - Inositol, La - Lactose, Ma - Maltose, Mn - Mannitol, Mo - Mannose, Mb - Melibiose, Rf - Raffinose, Sa - Salicin, Sb - Sorbitol, Su - Sucrose, Te - Trehalose, Xy - Xylose

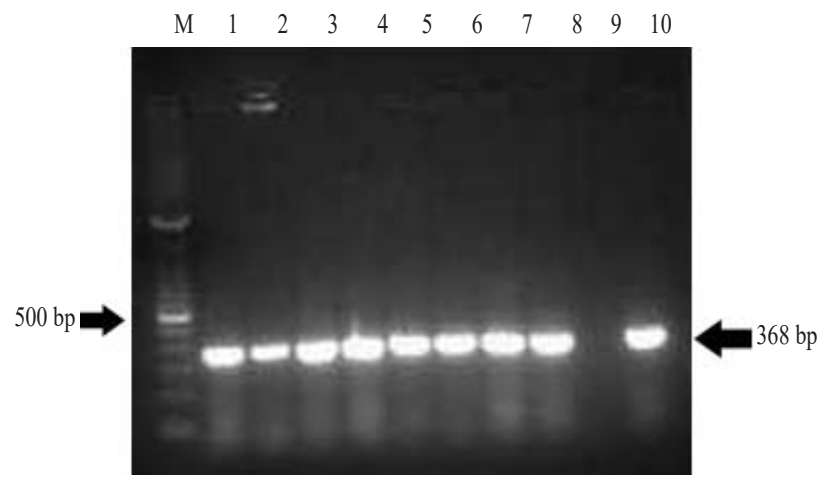

Lane $\mathrm{M}-100$ bp Marker

Lane 1 to 8 - Positive samples

Lane 9 - Negative control

Lane 10 - Positive control

Fig. 1. $V_{P}-$ toxR gene - Agarose gel showing the PCR product specific to toxR gene

reverse sequence, respectively. The PCR products of $t$ lh forward and reverse had 96 and 99\% percent homology with $V_{p}$ RIMD 2210633 chromosome 2. There was deletion of $\mathrm{A}$ at $15^{\text {th }}, 121^{\text {st }}$ and $160^{\text {th }}$, replacement of A with $\mathrm{C}$ at $118^{\text {th }}, \mathrm{C}$ with $\mathrm{T}$ at $144^{\text {th }}$ and $\mathrm{A}$ with $\mathrm{T}$ at $164^{\text {th }}$ positions in forward sequence while it was replacement of $\mathrm{T}$ with $\mathrm{G}$ at $11^{\text {th }}$ positions in reverse sequence, respectively (Ananda Raja et al., 2017b). Natural deletion (Tinwongger et al., 2014) and CAP induced mutation (Nithya Quintal et al., 2009) were

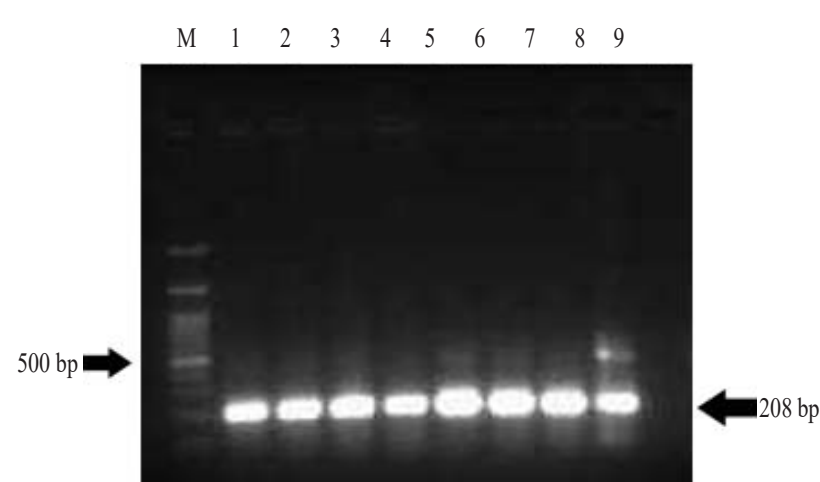

Lane M - 100 bp Marker

Lane 1 to 7 - Positive samples

Lane 8 - Negative control

Lane 9 - Positive control

Fig. 2. $V_{P}-t$ th (thermolabile haemolysin) gene - Agarose gel showing PCR product specific to th gene

possible in $V_{P}$ as demonstrated by earlier researchers. It needs further validation to find out the possibilities of deletion and mutation leading to the isolate becoming pathogenic to shrimp.

Differentiation of virulent bacterial strains from nonvirulent strains was difficult using traditional culture methods based on growth phenotypes (Takahashi et al., 2005). So, PCR assays are becoming increasingly popular for detection of pathogenic bacterial strains targeting 
virulent genes (Hossain et al., 2013). Compared to the conventional bacterial identification methods, PCR based molecular techniques were found to be rapid and reliable for accomplishing a comprehensive detection of $V_{P}$. Since, the percentage of rRNA (Kita-Tsukamoto et al., 1993) and gyrB (Venkateswaran et al., 1998) sequence homologies were more than 99 and $86.8 \%$ between $V_{P}$ and $V$. alginolyticus, respectively, tox $R$ gene was identified as a gene very specific to $V_{P}$. The tox $R$ gene was identified to be involved in the regulation of many other genes in $V$. cholerae (DiRita, 1992). But, the degree of homology of the toxR gene between $V_{P}$ and $V$. cholerae was only $52 \%$, which was much lower than that of the rRNA gene (92\% identity) (Kita-Tsukamoto et al., 1993; Kim et al., 1999). Kim et al. (1999) and Anjay et al. (2014) found that the toxR gene was well conserved among $V_{P}$ and therefore, they established a toxRtargeted PCR protocol for the specific detection of $V_{P}$. Yang et al. (2014) reported that the transcriptional activator toxR was constantly found in AHPND causing $V_{P}$ strains along with zona occludens toxin, accessory cholera enterotoxin and transmembrane regulatory protein tox $S$ but were not in other strains. Even though, the $V_{P}$ stains in the present study were positive to tox $R$ gene, they were constantly negative to AHPND causing AP1, AP2, AP3 $\left(\right.$ pir $A^{v p}$ ) and AP4 (pir $A^{v p}$ and pirB ${ }^{v p}$ ) genes (Kumar et al., 2014). Hossain et al. (2013) developed a multiplex PCR for detection of $V_{P}$ based on groEL, $t d h$ and $t r h$ genes with the sensitivity of $200 \mathrm{pg}$ DNA. The same level of sensitivity was observed in the present study in detecting the species-specific marker $t h$ and virulence marker tox $R$ genes.

Sahilah et al. (2014) characterised 44 genomic DNA of $V_{P}$ for the presence of tox $\mathrm{R}, t d h$ and $t r h$ gene and found 37 isolates positive towards tox $\mathrm{R}$ gene; while, none were positive to $t d h$ and $t r h$ genes as found in the present study. Disagreement to the present findings, Letchumanan et al. $(2015 \mathrm{a}, \mathrm{b})$ observed that 10 and $6.5 \%$ toxR-positive isolates exhibited the trh gene but none of the isolates were found positive for $t d h$. Many researchers reported that the possession of particular hemolysin genes $(t d h, t r h$ or both) was important to cause gastroenteritis in human (Bej et al., 1999; DePaola et al., 2003). However, a small portion of clinical strains carried neither of the genes, $t d h$ and trh (Banerjee et al., 2014). So, it could not be possible to ascertain that the $V_{P}$ isolates obtained in the present study were non-pathogenic to humans. The present study concluded that prevalence of $V_{P}$ in $P$. vannamei farms was high but no AHPND causing $V_{P}$ isolates were found in the samples tested. Continuous surveillance studies are required to monitor and detect AHPND emergence in India.

\section{Acknowledgements}

The authors express their deep sense of gratitude to Dr. K. K.Vijayan, Director, ICAR-Central Institute of Brackishwater Aquaculture (ICAR-CIBA), Chennai and Dr. S. V. Alavandi, Head, AAHED, ICAR-CIBA, Chennai for their constructive criticism and support extended towards this work.

\section{References}

Alday-Sanz, V., Roque, A. and Turnbull, J. F. 2002. Clearing mechanisms of Vibrio vulnificus biotype I in the black tiger shrimp Penaeus monodon. Dis. Aquat. Org., 48: 91-99.

Alsina, M. and Blanch, A. R. 1994. A set of keys for biochemical identification of environmental Vibrio species. J. Appl. Microbiol., 76: 79-85. doi.10.1111/j.1365-2672.1994tb04 419.x.

Ananda Raja, R., Panigrahi, A. and Sujeet Kumar 2012. Epidemiological investigation of brackishwater culture system of West Bengal. J. Appl. Aquac., 24: 49-59. doi.10. 1080/10454438.2012.652029.

Ananda Raja, R., Panigrahi, A., De, D. and Sujeet Kumar 2017a. White spot disease in Penaeus monodon associated with Vibrio mimicus in Sunderban India. Indian J. Fish., 64: 56-60. doi.10.21077/ijf.2017.64.1.54833-09.

Ananda Raja, R., Sridhar, R., Balachandran, C., Palanisammi, A., Ramesh, S. and Nagarajan, K. 2017b. Pathogenicity profile of Vibrio parahaemolyticus in farmed Pacific white shrimp, Penaeus vannamei. Fish Shellfish Immunol., 67: 368-381. doi.10.1016/j.fsi.2017.06.020.

Anjay Das, S. C., Kumar, A., Kaushik, P. and Kurmi, B. 2014. Occurrence of Vibrio parahaemolyticus in marine fish and shellfish. Indian J. Geo-Mar. Sci., 43: 887-890.

Antonio, N. L., Brock, J. A and Bauman, H. 2015. Limited decomposition enhances PCR detection of AHPND Vibrio in shrimp. GAA., 6: 66-67.

Banerjee, S. K., Kearney, A. K., Nadon, C. A., Peterson, C. L., Tyler, K., Bakouche, L., Clark, C. G., Hoang, L., Gilmour, M. W and Farber, J. M. 2014. Phenotypic and genotypic characterisation of Canadian clinical isolates of Vibrio parahaemolyticus collected from 2000 to 2009. J. Clin. Microbiol., 52: 1081-1088. doi:10.1128/JCM.03047-13.

Baumann, P. and Schubert, R. H. W. 1984. Family II. Vibrionaceae. Veron 1965, 5345. In: Krieg, N. R. and Holt, J. G. (Eds.), Bergey's manual of systematic bacteriology, Vol. 1. Williams and Wilkins, Baltimore, M. D., p. $516-550$.

Bej, A. K., Patterson, D. P., Brasher, C. W., Vickery, M. C. L., Jones, D. D. and Kaysner, C. A. 1999. Detection of total and hemolysin-producing Vibrio parahaemolyticus in shellfish using multiplex PCR amplification of $t l h, t d h$ and trh. J. Microbiol. Methods, 36: 215-225. 
Dangtip, S., Sirikharin, R., Sanguanrut, P., Thitamadee, S., Sriunyaluucksana, K., Taengchaiyaphum, S., Mavichak, R., Proespraiwong, P. and Flegel, T. W. 2015. AP4 method for two-tube nested PCR detection of AHPND isolates of Vibrio parahaemolyticus. Aquaculture Rep., 2: 158-162. doi.org/10.1016/j.aqrep.2015.10.002.

De Schryver, P., Defoirdt, T. and Sorgeloos, P. 2014. Early mortality syndrome outbreaks: a microbial management issue in shrimp farming? PLoS Pathog., 10(4), e1003919. doi:10.1371/journal.ppat.1003919.

DePaola, A., Nordstrom, J. L., Bowers, J. C., Wells, J. G. and Cook, D. W. 2003. Seasonal abundance of total and pathogenic Vibrio parahaemolyticus. Appl. Environ. Microbiol., 69: 1521-1526. doi: 10.1128/AEM.69.3.15211526.2003 .

DiRita, V. J. 1992. Co-ordinate expression of virulence genes by ToxR in Vibrio cholerae. Mol. Microbiol., 6: 451-458. doi: 10.1111/j.1365-2958.1992.tb01489.x.

FAO 2013. Report of the FAO/MARD technical workshop on early mortality syndrome (EMS) or acute hepatopancreatic necrosis syndrome (AHPNS) of cultured shrimp (under TCP/VIE/3304). Hanoi, Viet Nam, 25-27 June 2013. FAO Fisheries and Aquaculture Report No. 1053, Rome, 54 pp.

Flegel, T. W. and Lo, C. F. 2014. Free release of primers for specific detection of bacterial isolates that cause acute hepatopancreatic necrosis disease (AHPND). Network of Aquaculture Centres in Asia and the Pacific, Bangkok, Thailand. http://www.enaca.org/modules/library/publication. php?publication_id=1128. (Accessed 14 February 2015).

Han, J. E., Tang, F. F. J., Lightner, D.V. and Tran, L. 2015. Photorhabdus insect related (Pir) toxin-like genes in a plasmid of Vibrio parahaemolyticus, the causative agent of acute hepatopancreatic necrosis disease (AHPND) of shrimp. Dis. Aquat. Org., 113: 33-40. doi: 10.3354/ dao02830.

Hossain, M. Y., Kim, Y. O and Kong, I. S. 2013. Multiplex PCR for the detection and differentiation of Vibrio parahaemolyticus strains using the groEL, tdh and trh genes. Mol. Cell. Prob., 27: 171-175. doi: org/10.1016/j. mcp.2013.04.001.

Ishimaru, K., Akarawa-Matsushita, M. and Muroga, K. 1995. Vibrio penaeicida sp. nov., a pathogen of kuruma shrimps (Penaeus japonicus). Int. J. Syst. Bacteriol., 43: 8-19.

Janakiram, P., Jayasree, L., Sivaprasad, B., Veerendrakumar, M. and Geetha, G. K. 2013. Histopathological and bacteriological studies of monodon slow growth syndrome (MSGS) affected shrimps. Indian J. Fish., 60: 97-101.

Jayasree, L., Janakiram, P. and Madhavi, R. 2000. Characteristics, pathogenicity and antibiotic sensitivity of bacterial isolates from white spot diseased shrimp. Asian Fish. Sci., 13: 327-334.

Johnson, C. N., Bowers, J. C., Griffitt, K. J., Molina, V., Clostio, R. W., Pei, S., Laws, E., Paranjpye, R. N., Strom, M. S.,
Chen, A., Hasan, N. A., Huq, A., Noriea, N. F. III., Grimes, D. J. and Colwell, R. R. 2012. Ecology of Vibrio parahaemolyticus and Vibrio vulnificus in the coastal and estuarine waters of Louisiana, Maryland, Mississippi and Washington (United States). Appl. Environ. Microbiol., 78: 7249-7257.

Kim, Y, B., Okuda, J., Matsumoto, C., Takahashi, N., Hashimoto, S. and Nishibuchi, M. 1999. Identification of Vibrio parahaemolyticus strains at the species level by PCR targeted to the toxR gene. J. Clinic. Microbiol., 37: 1173-1177.

Kita-Tsukamoto, K., Oyaizu, H., Nanba, K. and Shimidu, U. 1993. Phylogenetic relationships of marine bacteria, mainly members of the family Vibrionaceae, determined on the basis of $16 \mathrm{~S}$ rRNA sequences. Int. J. Syst. Bacteriol., 43: 8-19.

Kumar, B. K., Deekshit, V. K., Raj, J. R. M., Rai, P., Shivanagowda, B. M., Karunasagar, I. and Karunasagar, I. 2014. Diversity of Vibrio parahaemolyticus associated with disease outbreak among cultured Litopenaeus vannamei (Pacific white shrimp) in India. Aquaculture, 433: 247-251. doi.org/10.1016/j.aquaculture.2014.06.016.

Lavilla-Pitogo, C. R., Baticados, M. C. L., Cruz-Lacierda, E. R. and de la Pena, R. 1990. Occurrence of luminous bacterial disease of Penaeus monodon larvae in the Philippines. Aquaculture, 91: 1-13. doi: 10.1016/0044-8486(90)90173-K.

Letchumanan, V., Pusparajah, P., Tan, LT-H., Yin, W-F., Lee, L-H. and Chan, K-G. 2015a. Occurrence and antibiotic resistance of Vibrio parahaemolyticus from shellfish in Selangor, Malaysia. Front. Microbiol., 6: 1417. doi: 10.3389/fmicb.2015.01417.

Letchumanan, V., Yin, W-F., Lee, L-H. and Chan, K-G. 2015b. Prevalence and antimicrobial susceptibility of Vibrio parahaemolyticus isolated from retail shrimps in Malaysia. Front. Microbiol., 6: 1-11. doi: 10.3389/fmicb.2015.00033.

Lightner, D. V., Redman, C. R., Pantoja, B. L., Noble, L. M., Nunan and Loc Tran 2013. Documentation of an emerging disease (Early mortality syndrome) in SE Asia and Mexico. OIE Reference Laboratory for Shrimp Diseases, Department of Veterinary Science and Microbiology, School of Animal and Comparative Biomedical Sciences. (Accessed 16 February 3016).

NACA 2012. Report of the Asia Pacific emergency regional consultation on the emerging shrimp disease: early mortality syndrome (EMS)/acute hepatopancreatic necrosis syndrome (AHPNS), 9-10 August 2012. Network of Aquaculture Centres in Asia-Pacific, Bangkok, Thailand.

Nithya Quintal, M., Porteen, K., Wilfred Ruban, S., Abraham, T. J. and Pramanik, A. K. 2009. Chloramphenicol induced mutation frequency of Vibrio parahaemolyticus strains isolated from freshwater fishes. Indian Vet. J., 86: 451-453.

Nordstrom, J. L., Vickery, M. C. L., Blackstone, G. M., Murray, S. L. and DePaola, A. 2007. Development of a multiplex 
real-time PCR assay with an internal amplification control for the detection of total and pathogenic Vibrio parahaemolyticus bacteria in oysters. Appl. Environ. Microbiol., 73: 5840-5847. doi.10.1128/AEM.00460-07.

Rosalind George, M. 2002. Characterization of Vibrio spp. from farm reared shrimps and coastal waters. $\mathrm{Ph} . \mathrm{D}$. Thesis, Department of Aquaculture, Fisheries College and Research Institute, Tamil Nadu Veterinary and Animal Sciences University, Thoothukudi, India.

Sahilah, A. M., Laila, R. A. S., Sallehuddin, H. M., Osman, H., Aminah, A. and Azuhairi, A. A. 2014. Antibiotic resistance and molecular typing among cockle (Anadara granosa) strains of Vibrio parahaemolyticus by polymerase chain reaction (PCR) based analysis. World J. Microbiol. Biotech., 30: 649-659. doi: 10.1007/ s11274-013-1494-y.

Silvester, R., Alexander, D. and Ammanamveetil, M. H. A. 2015. Prevalence, antibiotic resistance, virulence and plasmid profiles of Vibrio parahaemolyticus from a tropical estuary and adjoining traditional prawn farm along the south-west coast of India. Ann. Microbiol., 65: 2141-2149.

Sudha, S., Mridula, C., Silvester, R. and Hatha, A. A. M. 2014. Prevalence and antibiotic resistance of pathogenic vibrios in shellfishes from Cochin market. Indian J. Geo-Mar. Sci., 43: 815-824.

Takahashi, H., Hara-Kudo, Y., Miyasaka, J., Kumagai, S. and Konuma, H. 2005. Development of a quantitative real-time polymerase chain reaction targeted to the toxR for detection of Vibrio vulnificus. J. Microbiol. Methods, 61: 77-85. doi:10.1016/j.mimet.2004.11.005.

Tinwongger, S., Proespraiwong, P., Thawonsuwan, J., Sriwanayos, P., Kongkumnerd, J., Chaweepack, T., Mavichak, R., Unajak, S., Nozaki, R., Kondo, H. and Hirono, I. 2014. Development of PCR diagnosis method for shrimp acute hepatopancreatic necrosis disease (AHPND) strain of Vibrio parahaemolyticus. Fish Pathol., 49: 159-164.

Tran, L., Nunan, L., Redman, R. M., Mohney, L., Pantoja, C. R., Fitzsimmons, K. and Lightner, D.V. 2013. Determination of the infectious nature of the agent of acute hepatopancreatic necrosis syndrome affecting penaeid shrimp. Dis. Aquat. Org., 105: 45-55. doi.10.3354/dao02621.

Venkateswaran, K., Dohmoto, N. and Harayama, S. 1998. Cloning and nucleotide sequence of the $g y r B$ gene of Vibrio parahaemolyticus and its application in detection of this pathogen in shrimp. Appl. Environ. Microbiol., 64: 681-687.

Yang, Y. T., Chen, I. T., Lee, C. T., Chen, C. Y., Lin, S. S., Hor, L. I., Tseng, T. C., Huang, Y. T., Sritunyalucksana, K., Thitamadee, S., Wang, H. C. and Lo, C. F. 2014. Draft genome sequences of four strains of Vibrio parahaemolyticus, three of which cause early mortality syndrome/acute hepatopancreatic necrosis disease in shrimp in China and Thailand. Genome Announc., 2: e00816-14. doi:10.1128/genomeA.00816-14.

Zhang, B. C., Liu, F., Bian, H. H., Liu, J., Pan, L.Q. and Huang, J. 2012. Isolation, identification, and pathogenicity analysis of a Vibrio parahaemolyticus strain from Litopenaeus vannamei. Prog. Fish. Sci., 33: 56-62. (in Chinese with English abstract and figure illustrations).

Zhou, J., Fang, W., Yang, X., Zhou, S., Hu, L., Li, X., Qi, X., $\mathrm{Su}, \mathrm{H}$. and Xie, L. 2012. A nonluminescent and highly virulent Vibrio harveyi strain is associated with "Bacterial white tail disease" of Litopenaeus vannamei shrimp. PLoS ONE., 7: e29961. doi:10.1371/journal.pone.0029961.

Zorriehzahra, M. J. and Banaederakhshan, R. 2015. Early mortality syndrome (EMS) as new emerging threat in shrimp industry. Adv. Anim. Vet. Sci., 3: 64-72. doi: org/10.14737/journal.aavs/2015/3.2s.64.72. 